\begin{tabular}{|c|c|c|c|c|c|c|}
\hline \multirow{4}{*}{ Impact Factor: } & ISRA (India) & $=3.117$ & SIS (USA) & $=0.912$ & ICV (Poland) & $=6.630$ \\
\hline & ISI (Dubai, UAE & $=0.829$ & РИНЦ (Russia & $=0.156$ & PIF (India) & $=1.940$ \\
\hline & GIF (Australia) & $=0.564$ & ESJI (KZ) & $=8.716$ & IBI (India) & $=4.260$ \\
\hline & JIF & $=1.500$ & SJIF (Morocco & $=5.667$ & OAJI (USA) & $=0.350$ \\
\hline
\end{tabular}

\begin{tabular}{|c|c|}
\hline $\begin{array}{l}\text { SOI: } \underline{1.1 / \mathrm{TA}} \\
\text { International Sc } \\
\text { Theoretical } \boldsymbol{\&} \mathbf{A}\end{array}$ & $\begin{array}{l}\frac{S}{\text { DOI: }} \text { 10.15863/TAS } \\
\text { ientific Journal } \\
\text { pplied Science }\end{array}$ \\
\hline p-ISSN: 2308-4944 (print) & e-ISSN: 2409-0085 (online) \\
\hline Year: $2019 \quad$ Issue: 03 & Volume: 71 \\
\hline Published: 30.03 .2019 & http://T-Science.org \\
\hline
\end{tabular}

SECTION 31. Economic research, finance, innovation, risk management.
QR - Issue
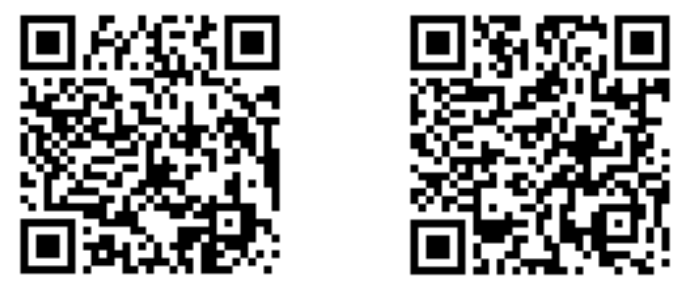

Sayyora Rikhsibaevna Safaeva

Candidate of economics, associate professor,

Tashkent state university of economics, Tashkent city, Republic of Uzbekistan

\title{
IMPROVING THE ORGANIZATIONAL, ECONOMIC AND INSTITUTIONAL MECHANISMS OF MANAGING THE SPHERE OF TOURISM IN UZBEKISTAN
}

Abstract: The article discusses the issues of improving the organizational, economic and institutional mechanisms for managing the tourism industry in Uzbekistan. The author concluded that the tourist services market is constantly expanding in all countries of the world, and that the Republic of Uzbekistan, as compared with other countries, is characterized by specific features of the tourist potential.

Key words: tourism, services, management, management, marketing, profit, tourist.

Language: English

Citation: Safaeva, S. R. (2019). Improving the organizational, economic and institutional mechanisms of managing the sphere of tourism in Uzbekistan. ISJ Theoretical \& Applied Science, 03 (71), 545-552.

Soi: http://s-o-i.org/1.1/TAS-03-71-54 Doi: crossef https://dx.doi.org/10.15863/TAS.2019.03.71.54

\section{Introduction}

In the transition to an innovative economy, the tourism industry is becoming one of the most promising areas. In many countries, the turnover of the tourism industry is tens of percent of GDP. Thus, according to the materials of the International Tourism Organization [8], the share of tourism in world GDP is about 9 percent and about 30 percent in world exports of services, 6 percent of world trade. More than 235 million people, or every 12 employees, work in the field of tourism.

According to the World Tourism and Travel Council, the indirect income of the tourism industry in 2016 was 3 trillion. US dollars [9], and mediated income amounted to 22,800 billion US dollars. The number of workers in the region exceeded 260 million people. It should also be said that over the past 20 years, tourist flows in the world have grown almost 2.2 times, from 435 million people in 1990 to 675 million people in 2000 and 940 people in 2010. In 2014, according to the World Tourism Organization, more than a trillion people traveled around the world. According to the forecasts of this organization, by 2020 the number of international tourist arrivals will exceed 1.5 billion, and revenues will increase to 2 trillion. USD. Below are data on the contribution of tourism to the GDP and employment of individual countries in 2016 (Fig. 1, 2).
Accordingly, increased attention to tourism from world organizations. The leaders of the G20 countries in a declaration following the annual meeting in 2014 recognized "the importance of the travel and tourism industry as a means of creating jobs, ensuring economic growth and development" and committed themselves "to develop initiatives to facilitate travel, which will help create jobs, ensuring decent work, reducing poverty and ensuring global economic growth "[10].

As world experience shows, to achieve economic growth, one of the promising areas is the effective use of the competitive advantages of the tourism sector. In this regard, Uzbekistan pays close attention to the development of the tourism sector, since in many regions there are favorable conditions for the development of this industry. Thus, in the main government document "Strategy of Action" [4], adopted at the initiative of President of the Republic of Uzbekistan Sh. Mirziyoyev, one of the main priorities was the accelerated development of the tourism industry, increasing its role and contribution to the economy, diversification and improvement of the quality of tourist services, expansion of tourist infrastructure. 


\begin{tabular}{|c|c|c|c|c|c|c|}
\hline \multirow{4}{*}{ Impact Factor: } & ISRA (India) & $=\mathbf{3 . 1 1 7}$ & SIS (USA) & $=0.912$ & ICV (Poland) & $=6.630$ \\
\hline & ISI (Dubai, UAE & $=0.829$ & РИНЦ (Russia & $=0.156$ & PIF (India) & $=1.940$ \\
\hline & GIF (Australia) & $=0.564$ & ESJI (KZ) & $=8.716$ & IBI (India) & $=4.260$ \\
\hline & JIF & $=1.500$ & SJIF (Morocco & $=5.667$ & OAJI (USA) & $=0.350$ \\
\hline
\end{tabular}

\section{Literature review}

The work of V.I. Azara, M.A. Ananeva, E.I. Ilina, G.A. Karpovoy, A.T. Kirillova, R. Yu. Popova, V.B. Saprunova, B.C. Seiina and other scientists. Regional aspects of tourism were considered in the works of V.G. Bogdanova, B.M. Birzhakova, L.A. Volkova et al. Basic research in the field of tourism management is reflected in the works of P.A. Braimera, E.I. Voronova, II.I.I. Kabushkina, V.A. Kvartalnova. Among the foreign experts working in this direction, we can mention P. Buckley, M. Brucke, R. Grande, D. Jeffreys, J. Kripendpendorf, and others.

There was several researches in field of effectively usage of industry potential by scientists as well as Zubarevich N.[10-11], Kazantsev S.V., Merenkova I.N., Nosov A.K., Panteleev A.P., Sepik D., Serebryakova L.A., Gulyamov S.S., Sadykov A.M., B. Ruzmetov, [12-13], research works about textile development in Uzbekistan investigated by young economists as Hakimov Z. and Tursunov B. [14-20]. Analysis of the works of these and other authors shows that by now certain prerequisites have been created, a range of basic organizational and economic ideas, provisions and approaches have been formed to improve the theory and practice of tourism management.

\section{Analysis and results}

In order to create favorable economic and organizational-legal conditions for the intensive development of tourism as a strategic sector of the country's economy, the most complete and effective use of the enormous tourist potential of the regions, a radical improvement in the management of the tourism industry, the creation and promotion of a national tourist product to world markets, and a positive image of Uzbekistan in the field of tourism, the Decree of the President of the Republic of Uzbekistan dated December 2, 2016 No. UP-4861 "On measures to Providing Accelerated Development of the Tourism Industry of the Republic of Uzbekistan ", which defines the target objectives and priorities of the state policy in the field of tourism in the medium term.

World practice shows that the growth of the service sector is one of the important directions of development of the modern economy. It should be noted that the share of services in developed countries ranges from $2 / 3$ to $3 / 4$ in gross domestic product (GDP). Along with this, stable growth in the service sector has a decisive impact on the level of employment of the population. In the Republic of Uzbekistan, the share of services in GDP in 2017 was $46.2 \%$ (Figure 1).

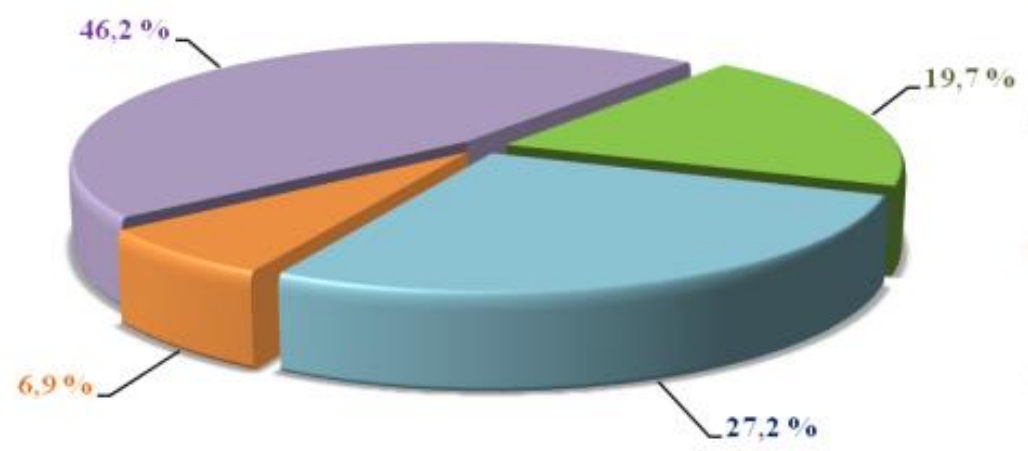

agriculture, forestry and fisheries

industry

building

services

Fig.1. GDP structure by branches of the economy in 2017

Currently, in the republic, 191.2 thousand operating organizations and enterprises are involved in the services sector, more than 136 thousand of them are small businesses (excluding farmers and dekhkan farms). 


\begin{tabular}{|c|c|c|c|c|c|c|}
\hline \multirow{4}{*}{ Impact Factor: } & ISRA (India) & $=3.117$ & SIS (USA) & $=0.912$ & ICV (Poland) & $=6.630$ \\
\hline & ISI (Dubai, UAE & $=0.829$ & РИНЦ (Russia & $=0.156$ & PIF (India) & $=1.940$ \\
\hline & GIF (Australia) & $=0.564$ & ESJI (KZ) & $=8.716$ & IBI (India) & $=4.260$ \\
\hline & JIF & $=1.500$ & SJIF (Morocco & $=5.667$ & OAJI (USA) & $=0.350$ \\
\hline
\end{tabular}

As a rule, for the implementation of most of the tourism projects do not require significant budgetary funds, first of all it needs the organizational efforts of the authorities to create an effective system of management of the industry. For these purposes, an authorized state body in the field of tourism has been created - the State Committee of the Republic of Uzbekistan for the development of tourism on the basis of the abolished national company Uzbektourism, whose main functions are: licensing tourism and tour operator activities; carrying out, in close cooperation with the national certification body of the Republic of Uzbekistan, the agency Uzstandard, of compulsory certification of tour operators (tourist products) and hotel services provided by tourist activities, including the establishment of a classification of hotels (motels) of various organizational and legal forms; implementation of inspection control over the compliance of certified tourist services with the mandatory requirements and standards set forth in regulatory documents.

The committee is entrusted with the main tasks [1] to ensure the formation and implementation of a holistic concept of tourism development, aimed at fundamentally increasing the country's tourism potential, giving tourism the status of a strategic sector of the economy, pursuing a unified state tourism policy; implementation of marketing research in the external and domestic markets of tourist services, implementation of an active advertising and information policy in the field of tourism, aimed at widely promoting the historical and cultural heritage, preserving and developing the tourist image of the Republic of Uzbekistan, promoting national tourism products and brands to international tourist markets; coordinating the development and monitoring of the implementation of national and regional programs for the integrated development of domestic, inbound and outbound tourism, accelerated development of a wide range of types of tourism, attracting foreign investment, as well as loans and grants from international financial institutions and other organizations to develop tourism infrastructure that meets international standards.

World Statistics Review
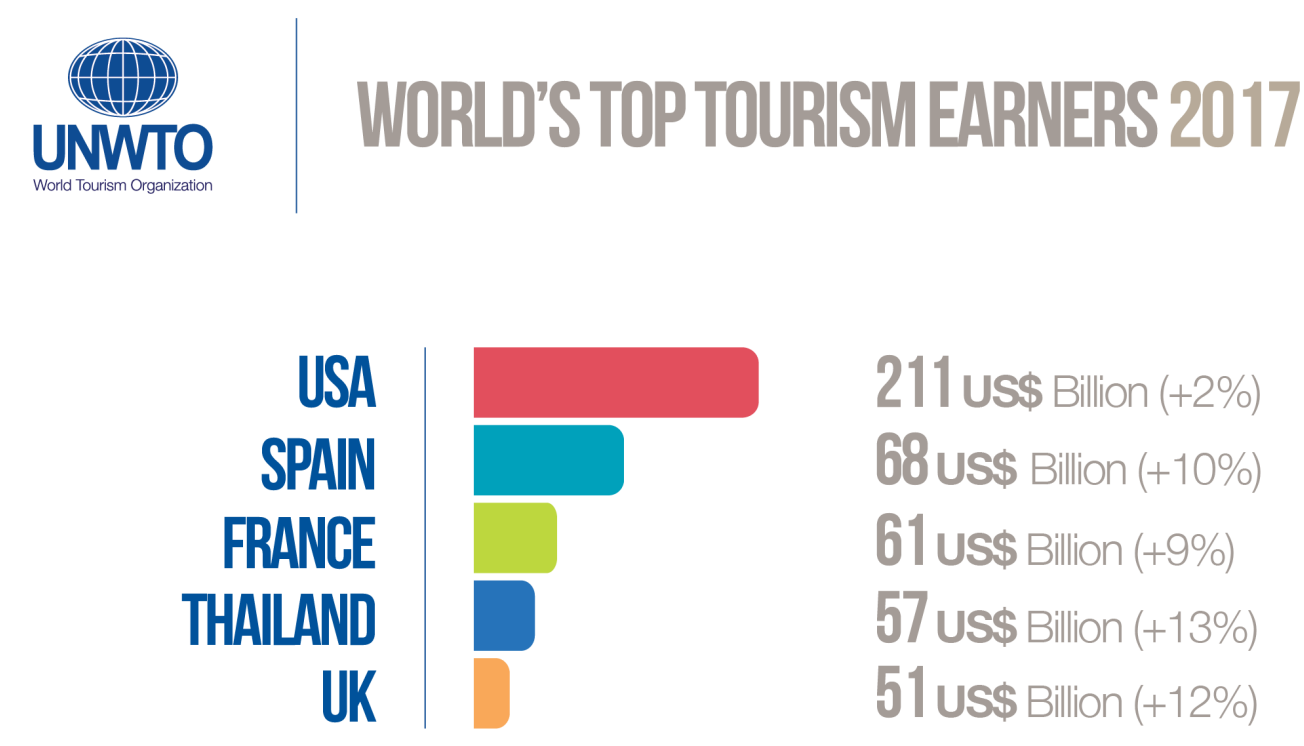

Source: @ UNWTO Tourism Highlights 2018 - World Tourism Organization (UNWTO), August 2018

Source: http://media.unwto.org/content/infographics

At Responsible Travel we speak with hundreds of customers every day about their holiday plans. We reviewed and judged more than 5000 of the best examples of Responsible Tourism globally through our World Responsible Tourism Awards. We have relationships with over 400 tour operators and many activist NGO's who bring us the latest ethical and cause related issues, from which we form our campaigning strategies. We've put all this 


\begin{tabular}{|c|c|c|c|c|c|c|}
\hline \multirow{4}{*}{ Impact Factor: } & ISRA (India) & $=\mathbf{3 . 1 1 7}$ & SIS (USA) & $=0.912$ & ICV (Poland) & $=6.630$ \\
\hline & ISI (Dubai, UAE & $=0.829$ & РИНЦ (Russia & $=0.156$ & PIF (India) & $=1.940$ \\
\hline & GIF (Australia) & $=0.564$ & ESJI (KZ) & $=8.716$ & IBI (India) & $=4.260$ \\
\hline & JIF & $=1.500$ & SJIF (Morocco & $=5.667$ & OAJI (USA) & $=0.350$ \\
\hline
\end{tabular}

experience together in to 5 big ideas and trends that we think will shape the future of tourism.

\section{A graph revealing approximate tourist}

\section{arrivals in millions}

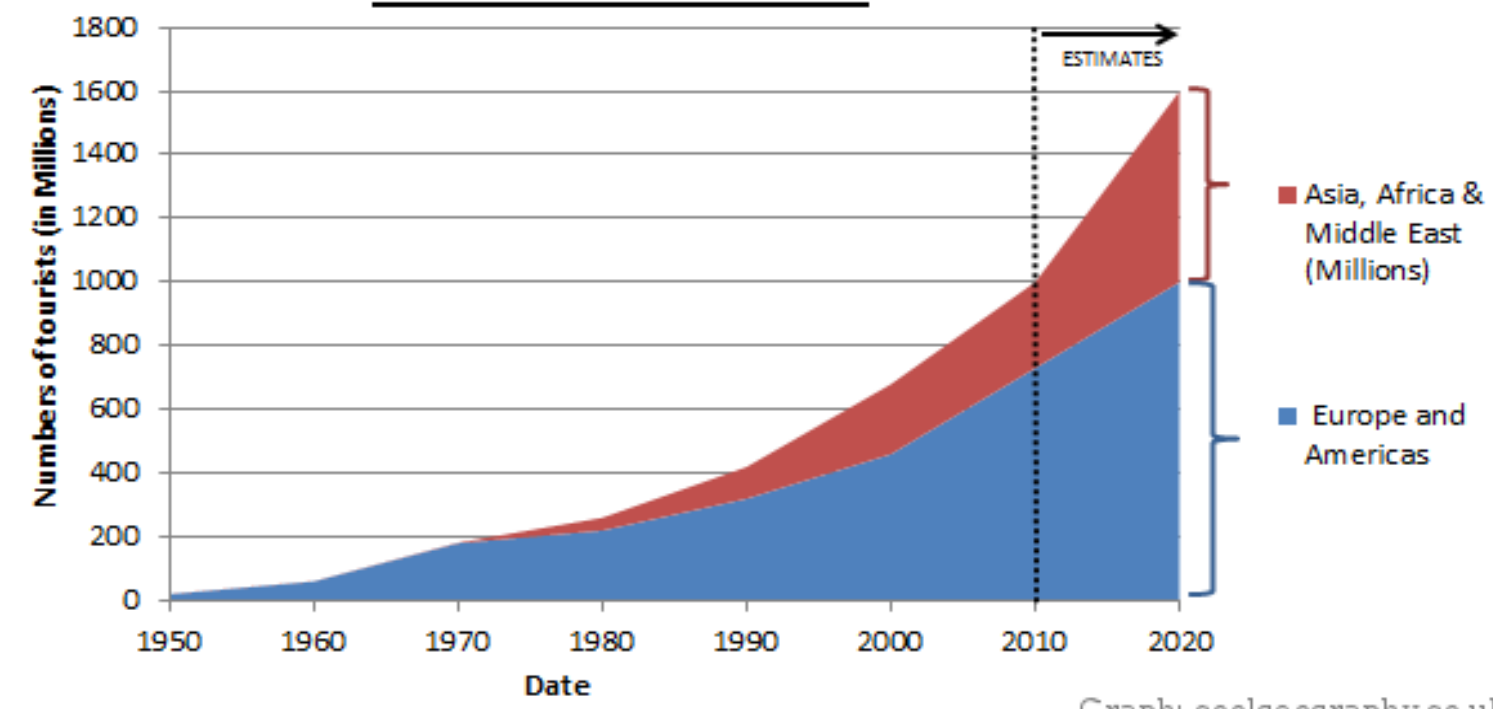

Source: www.responsibletravel.com/holidays/responsible-tourism/travel-guide/the-future-of-travel-and-tourism.

From now on efforts will be made to attract the 'right type of tourist' and where necessary numbers controlled through reducing bed night capacity, charging for entry, pre booking with fixed numbers, subsidising less flights, restricting cruise ship numbers and promoting less well known areas. More often than not the 'right type' of tourist will be the responsible tourist - creating the maximum benefit to local economies with the least possible social and environmental impact.

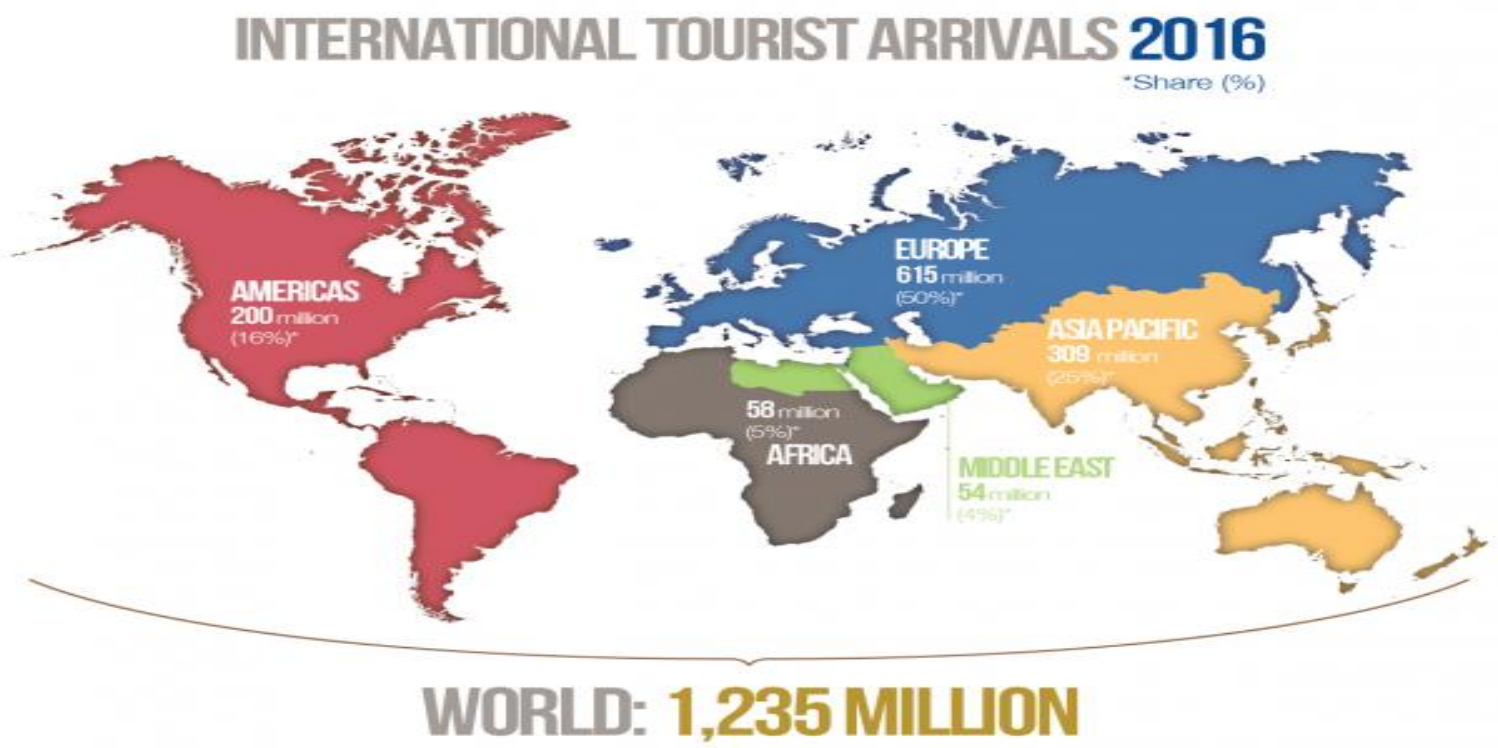

Source: http://media.unwto.org/content/infographics 


\begin{tabular}{|c|c|c|c|c|c|c|}
\hline \multirow{4}{*}{ Impact Factor: } & ISRA (India) & $=3.117$ & SIS (USA) & $=0.912$ & ICV (Poland) & $=6.630$ \\
\hline & ISI (Dubai, UAE & $=0.829$ & РИНЦ (Russia & $=0.156$ & PIF (India) & $=1.940$ \\
\hline & GIF (Australia) & $=0.564$ & ESJI (KZ) & $=8.716$ & IBI (India) & $=4.260$ \\
\hline & JIF & $=1.500$ & SJIF (Morocco & $=5.667$ & OAJI (USA) & $=0.350$ \\
\hline
\end{tabular}

\section{Directions for improving the tourism management mechanism}

One of the highlights of the development of the tourism industry is the organization of a visa-free regime for tourists. In this regard, and in order to create the most favorable conditions for the development of the tourist potential of the republic, primarily through the active attraction of investments, the introduction of innovative ideas and technologies in this area, the full use of the existing capabilities and resources of the country's rich natural, cultural and historical heritage, Since February 10, 2018, a visafree regime has been established for a period of 30 days from the date of entry into the territory of the Republic of Uzbekistan for citizens of the State of Israel, the Republic of Indonesia, the Republic of Korea, Malaysia, the Republic of Singapore, the Republic of Turkey and Japan, members of crews of aircraft of foreign airlines operating regular flights to the Republic of Uzbekistan, and a simplified procedure for obtaining tourist visas, which provides for the abolition of the requirement to submit a tourist voucher or request legal invitation to the Ministry of Foreign Affairs. individuals in the Republic of Uzbekistan and a visa within two working days, not counting the day of receiving the documents.

In addition, the country pays special attention to the development of domestic tourism. Thus, in order to ensure the accelerated development of domestic tourism as one of the most important factors for sustainable socio-economic development of the regions, familiarizing citizens with the cultural and historical heritage and natural resources of the country, a plan of practical measures to implement the program of development of domestic tourism "Uzbekistan boilab saejat Kil!"” Was approved. as well as a list of areas and cities with high potential for the development of domestic tourism.

This served to intensify work on the organization and development of the tourism sector in the regions. Thus, the list of projects for the creation and reconstruction of the existing tourist infrastructure, the creation of guest houses, a calendar of cultural, entertainment and sports events in the Surkhandarya region in 2018-2019 have been approved. In addition, this region provides for the creation of three small tourism zones (Baysunskaya, which includes the territory of the village of Omonkhona, the mountainous territory of Zovboshi and the territory of the village of Darband, located in the Baysunsky district, Sariasinskaya - the slopes of the Honzhiz mountain system located in the Sariasinsky and Uzunsky districts, the territory of the village Sangardak, Sariasinsky district, and Sherabadskaya the territory of the village Honzhiza, the salt field "Khujaikon" and fruit orchards, located in the Sherabad district).
In other regions of the republic, measures are also being taken to further develop and improve the management of the tourism sector. For example, in the Tashkent region, in order to create favorable conditions for the broad involvement of foreign and local tourists in the region, to ensure the dynamic development of modern infrastructure, expand and improve the quality of tourist, hotel and transport services, it is planned to create the Charvak free tourist zone within Chimgan-Charvak the resort and recreation zone of the Tashkent region, as well as the construction of modern hotel complexes and cultures on the territory of the free tourist zone aboutrecreation, shopping and entertainment facilities and other tourist destination, creating objects of modern engineering infrastructure. In addition, a number of tasks and directions for the development of this zone are defined.

In addition, the fast pace of changes in society, the informatization of all processes, the change in the social portrait of consumers of the tourist product and the new challenges facing the whole country dictate the need for a qualitative change in the approach to the organization of tourist infrastructure. Today it is necessary to build on the growing and growing complexity of the needs of target consumers. To do this, it is necessary to identify the most promising types of tourism that require targeted development in each region of Uzbekistan, and to develop plans to bring the tourist infrastructure in line with the specific needs of the real and target audience.

Based on the analysis of the experience of foreign countries, as well as taking into account the existing opportunities and the resource potential of our country as a whole, and regions in particular, the following types of tourism can be considered to require close attention and the most promising from the standpoint of sustainable socio-economic development of the economy of the country and regions of Uzbekistan due to increase in domestic and inbound tourist flow:

- cultural and educational;

- youth;

- children's and youthful, including excursion programs for schoolchildren and students of vocational educational institutions;

- fishing and hunting;

- rural;

- ecological;

- therapeutic and health;

- sporty.

The above list is not exhaustive, each region has the right to independently determine its specialization in the tourism plan and develop those types of tourism that most closely match the available tourist resources. However, the above list demonstrates the focus of modern state policy on creating conditions for the growth of cultural potential, health and quality of life 


\begin{tabular}{|c|c|c|c|c|c|c|}
\hline \multirow{4}{*}{ Impact Factor: } & ISRA (India) & $=3.117$ & SIS (USA) & $=0.912$ & ICV (Poland) & $=6.630$ \\
\hline & ISI (Dubai, UAE & $=0.829$ & РИНЦ (Russia & $=0.156$ & PIF (India) & $=1.940$ \\
\hline & GIF (Australia) & $=0.564$ & ESJI (KZ) & $=8.716$ & IBI (India) & $=4.260$ \\
\hline & JIF & $=1.500$ & SJIF (Morocco & $=5.667$ & OAJI (USA) & $=0.350$ \\
\hline
\end{tabular}

of the citizens of Uzbekistan and their guests. Also, these types of tourism have significant reserves for growth in terms of the availability of potential demand and tourist resources.

The implementation of the above and other measures to further develop and improve the management of the tourism industry in the Republic of Uzbekistan will not only increase tourism potential and increase investment in this area, but also improve the well-being of the population, the improvement of the regions as a whole through the creation of new competitive jobs and modern tourism infrastructure.

Conclusion

The existing mechanism of tourism development does not fully reflect these features. Therefore, the improvement of the organizational and economic mechanism of this sector development in Uzbekistan is among topical issues. The main elements of this mechanism are the principles, methods, tools and forms of its implementation.

The principles, methods and forms of the organizational and economic mechanism development, the aggregate of effective organizational and economic tools create the concept of organizational and economic mechanism of the development of a particular object.

The goal of the development of tourism through the same mechanism is to regulate the management process by influencing the management object. The nature of this effect is determined by the following characteristics of the modern economy:

- diversity of forms of ownership;

- State interference in the economy;

- unstable economic relations development;

- Mechanism of price formation;

- Competitiveness of tourist routes, operators and separate enterprises;

- Globalization.

Taking into account the above mentioned features, the following basic principles of organizational and economic mechanism of tourism development can be formulated:

- The principle of self-organization means that individual subjects of tourist activity have their own interests independently;

- The principle of efficiency, the choice of methods and means of action leading to achievement of the goals set by the management bodies, as well as the coordination of objectives of the subject and object of the management object;

- the principle of economics, the interest in selecting the organizational and economic mechanism of tourism development that provides the achievement of the goal of achieving the goal, using the least labor and material resources;

- the principle of completeness and coordination of the effects, ie the most effective functioning of the organizational and economic mechanism, is achieved by providing a comprehensive and equal measure to the object;

- The principle of synchronization of centralized and centralized management;

- directed to economic stimulation of the organizational and economic mechanism of the sector development;

- The principle of using these mechanism tools on the basis of integration and implementation of management techniques.

Strategic management managers will have the flexibility to use existing resources optimally, and have the ability to respond effectively to the environmental requirements of the organization, and will contribute to the development of cutting-edge transformation that will allow for productive work and longevity.

Sustainable development calls for an understanding of the processes that are planned, structured, controlled, and coordinated, transforming unwanted elements (structures, technologies, products, production links, etc.) into existing developers. Managed development is carried out within the framework of the network strategy and is aimed at ensuring the economic security and development of the subject.

The following seven principles have been laid down in the concept of a strategic management mechanism for sustainable tourism development:

- maximize the satisfaction of tourists;

- Provision of reproduction and preservation of historical and cultural heritage;

- Ensuring environmental and socio-economic safety;

- conformity to type of external environment change of type of transformation;

- combination of administrative management with organic structure and horizontal relations;

- ensuring the strategic management development process;

- Compliance of the interests of economic entities;

- Continuous improvement.

It sets out the principles that are essential to the sustained development of the principles of sustainable development, initiated by the organizational and economic mechanism and managing the process of economic transformation.

Methods of impact on network systems can generally be classified in the management approach. It takes the economic, administrative, and sociopsychological effects of the impact. This classification can be used only when applied to our task, but excludes social and psychological methods of influence on the basis of social norms.

The main method of economic impact on the market economy is the balance of demand and supply. Taking into account the emphasis on attracting foreign 


\begin{tabular}{|c|c|c|c|c|c|c|}
\hline \multirow{4}{*}{ Impact Factor: } & ISRA (India) & $=3.117$ & SIS (USA) & $=0.912$ & ICV (Poland) & $=6.630$ \\
\hline & ISI (Dubai, UAE & $=0.829$ & РИНЦ (Russia & $=0.156$ & PIF (India) & $=1.940$ \\
\hline & GIF (Australia) & $=0.564$ & ESJI (KZ) & $=8.716$ & IBI (India) & $=4.260$ \\
\hline & JIF & $=1.500$ & SJIF (Morocco & $=5.667$ & OAJI (USA) & $=0.350$ \\
\hline
\end{tabular}

tourists in our country, the person who can be called a "global tourist" has a huge market of services that can be selected from a wide range of tourist services in its tens of countries, depending on its budget, cultural and other restrictions you need to understand that you are talking about. Though restrictions may be imposed on the functioning of the market economy mechanism in the country, the national network can generally be seen as part of a market mechanism that shapes the supply of services.

Developing economies are characterized by a high level of stability and a risk of conflict. Therefore, in the network system, besides the market mechanism, the regulatory impacts of public associations, public organizations and business associations should play an important role.

According to the principles of the organizational and economic mechanism, influence on the subjects of the tourist market should be systematic, comprehensive and balanced. This is achieved through the coordination and co-operation of all groups. Systematization and coordination of the impact of the organizational and economic mechanism will be achieved through the creation of software techniques to achieve a comprehensive strategic objective of developing a tourism complex.

Along with the methodology and process of organizational-economic mechanism of tourism development, it is also important to ensure it.
Moreover, according to the principles, the organizational-economic mechanism should be created in accordance with available resources. The main sources of modern organizational and economic mechanisms of development are information, qualifications, financial, social, cultural and communication resources.

The information resources of this mechanism provide the collection and processing of information both on-country and on tourist activity, as well as on the organizational-economic mechanism of its operation, for the assessment and decision-making of tourist companies. Qualified resources play an important role. This is because the organizational and economic mechanism of tourism determines the credibility of the use of separate methods and means. In many cases, they are the main deterrent. If the planned organizational-economic mechanism is not provided with the necessary quantities and qualifications, it can be implemented and operated in accordance with the given parameters.

\section{References:}

1. (2016). "On the organization of the activities of the State Committee of the Republic of Uzbekistan on tourism development". Decree of the President of the Republic of Uzbekistan dated December 2, 2016 No. PP-2666.

2. (2017). "On the strategy of actions for the further development of the Republic of Uzbekistan". Decree of the Presidential Republic of Uzbekistan of February 7, 2017, No. UP-4947

3. (2017). "On the creation of the free tourist zone Charvak". Decree of the President of the Republic of Uzbekistan of December 5, 2017 No. UP 5273

4. (2018). "On additional organizational measures to create favorable conditions for the development of the tourist potential of the Republic of Uzbekistan". Decree of the President of the Republic of Uzbekistan dated February 3, 2018, No.UP-5326

5. Saprunova, V. B. (2014). Tourism: evolution, structure, marketing. (p.160). Moscow: Os-89.
6. (n.d.). Travel and tourism is the second largest US services export "Travel Business Roundtable". Retrieved 2019, from www.tbr.org

7. (2004). Tourism Highlights. (p.15). Madrid: UNWTO.

8. Mirsayakova, V. A. (2016). Znachenie turizma v mirovoy ekonomike. Molodoy uchenyy, №5.5, 17-19. https://moluch.ru/archive/109/26821/

9. Safaeva, S., \& Ishanhojaeva, D. (2018). Organizatsionno-ekonomicheskie predposylki razvitiya i upravleniya sferoy turizma $\mathrm{v}$ Uzbekistane. Biznes-expert, Vol 12 (132).

10. Zubarevich, N. (n.d.). Regional Development and Institutions. Expert Portal of the Higher School of Economics "Open Economy". Retrieved 2019, from OPEC.ru

11. Kazantsev, S. V. (2004). The economic potential of the regions of Russia as the basis of their internal competitiveness. Region, № 1 . 


\begin{tabular}{|c|c|c|c|c|c|c|}
\hline \multirow{4}{*}{ Impact Factor: } & ISRA (India) & $=3.117$ & SIS (USA) & $=0.912$ & ICV (Poland) & $=6.630$ \\
\hline & ISI (Dubai, UAE & $=0.829$ & РИНЦ (Russia) & $=0.156$ & PIF (India) & $=1.940$ \\
\hline & GIF (Australia) & $=0.564$ & ESJI (KZ) & $=8.716$ & IBI (India) & $=4.260$ \\
\hline & JIF & $=1.500$ & SJIF (Morocco) & $=5.667$ & OAJI (USA) & $=0.350$ \\
\hline
\end{tabular}

12. Gulyamov, S. S. (1980). Modeling the socioeconomic development of territorial-industrial complexes. (p.194). Taskent: Fan.

13. Sadykov, A. M. (2005). Fundamentals of regional development: theory, methodology, practice. Monograph. (p.280). Tashkent: IQTISOD - MOLIYA.

14. Ibragimov, I. U., \& Tursunov, B. O. (2017). Enhancement the mechanism of analyzing of the methodological principles for the development and improvement of methods of assessment. Audit, № 4, 11-13.

15. Tursunov, B. O. (2017). osnovnye napravleniya podderzhki malogo biznesa $\mathrm{v}$ uzbekistane $\mathrm{i}$ zarubezhnyy opyt razvitiya predprinimatel"stva. Audit, № 6, 34-38.

16. Tursunov, B. O. (2017). teoreticheskie aspekty proizvodstvennoy moshchnosti tekstil"nykh predpriyatiy $\mathrm{v}$ sovremennykh usloviyakh.
Nauchno-analiticheskiy zhurnal Nauka $i$ praktika Rossiyskogo ekonomicheskogo universiteta im. G.V. Plekhanova, № 4 (28), 5768.

17. Tursunov, B. O. (2017). principles and functions of management of production capacity. Voprosy upravleniya, № 3 (46), 174-178.

18. Tursunov, B. O. (2017). upravlenie proizvodstvennymi zapasami v tekstil"nykh predpriyatiyakh. Nauchnaya mysl', T. 1, № 3 (25), 117-125.

19. Tursunov, B. (2017). Features of the method of calculation of production capacities of the textile enterprises. Byulleten' nauki i praktiki, № 10 (23), 213-222.

20. Tursunov, B. (2017). Ways of increasing the efficiency of usage the production capacity of textile enterprises. Byulleten' nauki i praktiki, № 8 (21), 232-242. 